\title{
Which antibody functions are important for an HIV vaccine?
}

\author{
Bin Su and Christiane Moog* \\ INSERM U1109, Fédération de Médecine Translationnelle de Strasbourg, Université de Strasbourg, Strasbourg, France
}

\section{Edited by:}

Marc H. V. Van Regenmortel, University of Strasbourg, France

\section{Reviewed by:}

Gabriella Scarlatti, Fondazione Centro San Raffaele, Italy

Kristina Broliden, Karolinska Institutet, Sweden

Marc H. V. Van Regenmortel,

University of Strasbourg, France

*Correspondence:

Christiane Moog, INSERM U1109,

Fédération de Médecine

Translationnelle de Strasbourg,

Université de Strasbourg, 3 rue

Koeberlé, Strasbourg 67000, France

e-mail:c.moog@unistra.fr
HIV antibody (Ab) functions capable of preventing mucosal cell-free or cell-to-cell HIV transmission are critical for the development of effective prophylactic and therapeutic vaccines. In addition to $\mathrm{CD} 4^{+}$T cells, other potential HIV-target cell types including antigen-presenting cells (APCs) (dendritic cells, macrophages) residing at mucosal sites are infected. Moreover, the interactions between APCs and HIV lead to HIV cell-to-cell transmission. Recently discovered broadly neutralizing antibodies (NAbs) are able to neutralize a broad spectrum of HIV strains, inhibit cell-to-cell transfer, and efficiently protect from infection in the experimentally challenged macaque model. However, the $31 \%$ protection observed in the RV144 vaccine trial in the absence of detectable NAbs in blood samples pointed to the possible role of additional $\mathrm{Ab}$ inhibitory functions. Increasing evidence suggests that IgG Fc $\gamma$ receptor (Fc $\gamma \mathrm{R}$ )-mediated inhibition of Abs present at the mucosal site may play a role in protection against HIV mucosal transmission. Moreover, mucosal IgA Abs may be determinant in protection against HIV sexual transmission. Therefore, defining Ab inhibitory functions that could lead to protection is critical for further HIV vaccine design. Here, we review different inhibitory properties of HIV-specific Abs and discuss their potential role in protection against HIV sexual transmission.

Keywords: HIV, mucosal HIV vaccine, cell-to-cell transfer, neutralizing antibodies, non-neutralizing inhibitory antibodies, $\mathrm{Fc} \gamma \mathrm{R}$, antigen-presenting cells, ADCC

\section{INTRODUCTION}

Sexual transmission is currently the major route of HIV infection worldwide. In more than $80 \%$ of newly diagnosed cases of HIV-1 infection, the patients become infected during sexual intercourse (1). This route of infection can be prevented by IgG neutralizing antibodies (NAbs) and secretory IgA $(2,3)$. Recently discovered potent and broadly NAbs (bNAbs) are able to neutralize a broad spectrum of cell-free and cell-associated HIV strains (4-13). These antibodies (Abs) have also been shown to efficiently protect nonhuman primates (NHP) and humanized mice from experimental challenge (14-20). However, bNAbs display very specific characteristics and are extremely difficult to induce since only $10-30 \%$ of patients develop such Abs (21-25) and attempts to induce them by vaccination have failed. bNAbs are characterized by uncommonly long complementarity-determining loops and extensive somatic hypermutation, suggesting the need for a long maturation process, which makes their induction by vaccination extremely difficult.

Interestingly, the limited $31 \%$ protection observed in the RV144 vaccine trial in the absence of detectable NAbs in plasma/serum specimens pointed to a possible role of additional $\mathrm{Ab}$ inhibitory functions in this protection $(26,27)$ and defining these additional functions is therefore critical. Increasing evidence suggests that IgG Fc $\gamma$ receptor $(\mathrm{Fc} \gamma \mathrm{R})$-mediated inhibition of Abs, leading to phagocytosis or antibody-dependent cellular cytotoxicity (ADCC), plays a role in protection. These $\mathrm{Fc} \gamma \mathrm{Rs}$ are expressed on various antigen-presenting cells (APCs) and natural killer (NK) cells present at the mucosal site, suggesting that Fc-mediated inhibitory functions may contribute to the blockage of mucosal transmission. These cells may play a decisive role during sexual transmission since they have been proposed to be the first HIV targets at the mucosal site (28-30). Evidence from in vivo studies showed that HIV-specific Abs displaying Fc-mediated inhibition in the absence of neutralizing activity is able to decrease the viral load after experimental vaginal challenge in the macaque model $(31,32)$. Besides, various Ab inhibitory functions at the mucosal site such as aggregation, complement inhibition, inhibition of HIV transfer, and inhibition by induction of antiviral cytokines and chemokines may also contribute to HIV protection. In addition to the induction of NAbs, new vaccination strategies based on such $\mathrm{Ab}$ activities, should be considered. In the present review, HIV inhibition by Abs based on these various potential inhibitory functions will be discussed, as well as its possible contribution to the development of new vaccination strategies.

\section{HIV-1 TRANSMISSION THROUGH MUCOSAL TISSUES}

Very little is known about how HIV infects and disseminates through mucosal tissues. The selection of transmitted/founder (T/F) virus occurs at the mucosal portal of HIV entry (3338). Mucosal sites contain a variety of immune cells targeted by HIV, i.e., APCs comprising various types of dendritic cells (DCs), macrophages, NK cells, and CD4 T lymphocytes (28-30, 39-43) (Figure 1). However, the exact mechanism by which viral particles migrate through the epithelial barrier remains unclear. Various modes of infection have been proposed, which include transfer through epithelial cells and intestinal epithelium, transport of HIV via DCs present at mucosal surfaces, and direct infection of resident CD4 T cells (41, 44-48) (Figure 1). Apart from direct infection of immune cells by cell-free virus, cell-to-cell transmission has been suggested to play a major role in HIV propagation and dissemination in vivo. Spread of HIV infection by cell-to-cell 


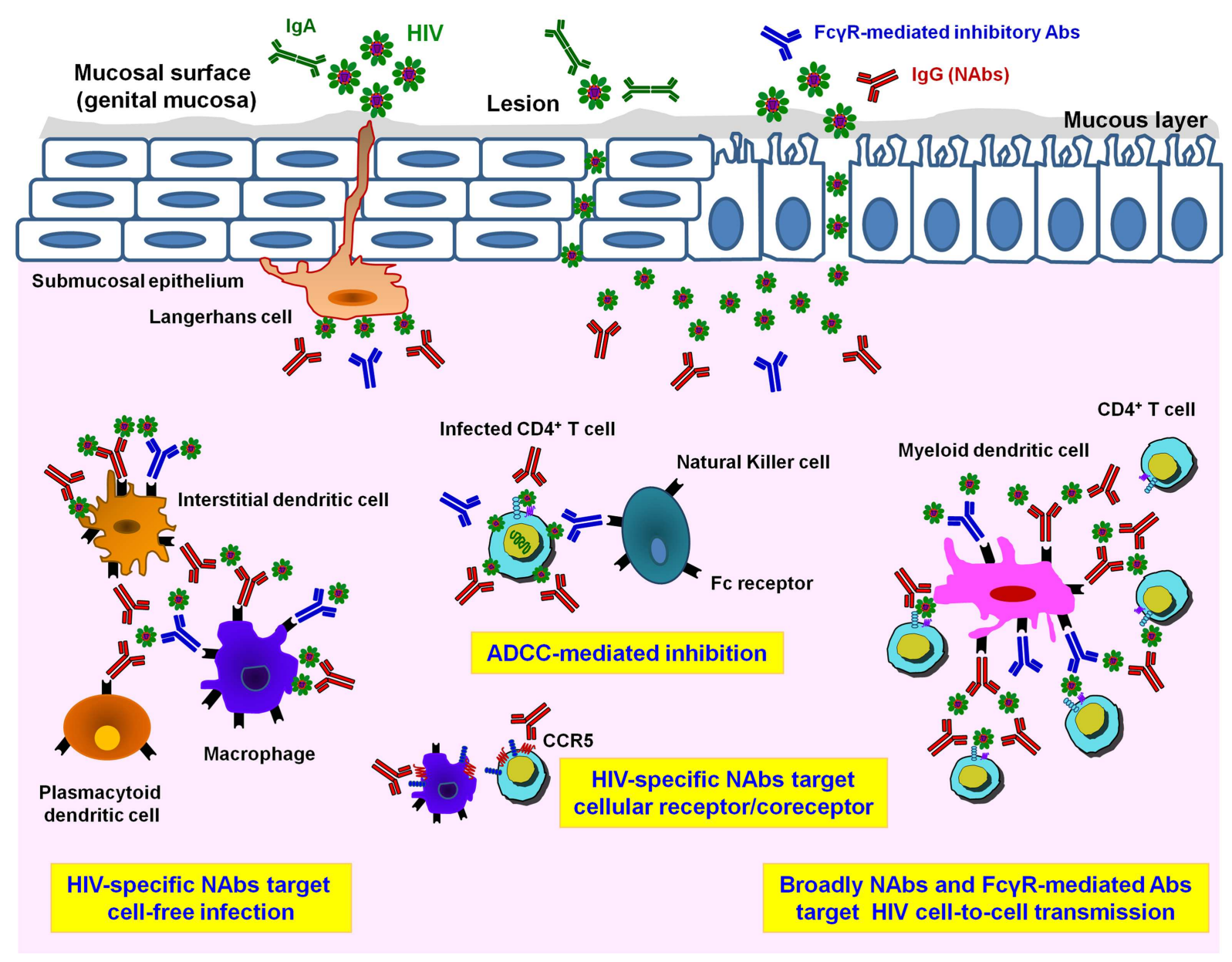

FIGURE 1 | Different HIV-1 antibody activities in mucosal tissues. Infectious HIV-1 particles can cross a multi-cellular layer of stratified squamous epithelial cells in genital mucosal tissues. Both cell-free and cell-associated HIV-1 virions infect host cells. Langerhans cells transport the virus into the sub-epithelium and mucosal lesions may provide an accessible pathway for HIV-1. In the sub-epithelium, in addition to target CD4+ T cells, other potential HIV-target cell types including myeloid dendritic cells (DCs) and macrophages are infected either by cell-free virions or by cell-associated virions. Mucosal HIV-specific IgA (IgA, in green) can bind and neutralize cell-free virus at mucosal surfaces. Adaptive immune responses such as HIV-1-specific IgG neutralizing antibodies (NAbs, in red) are important for preventing HIV-1 cell-free infection. Only NAbs are able to inhibit HIV infection of CD4 T lymphocytes while both NAbs and Fc $\gamma$ R-mediated inhibitory Abs (in blue) help to inhibit the spread of infection via cell-to-cell transmission route. Prevention of HIV-1 infection and killing of virus-producing cells by Ab-dependent mechanisms, especially antibody-dependent cellular cytotoxicity (ADCC) via binding of Fc receptors presented on the surface of innate immune cells such as natural killer (NK) cells, monocytes, DCs, or macrophages, takes place by inhibiting viral replication and diminishing viral reservoirs in vivo. Moreover, inhibitory NAbs directed to cellular target epitopes, such as CCR5 or other HIV-receptor/co-receptor structures, could provide additional targets for the rational design of novel vaccine candidates. transmission has been found to be 100 - to 1000 -fold more efficient than infection by cell-free virions (49-54). At the mucosal level, in addition to CD4 T cells many cells are targeted by direct cell-free or cell-associated HIV-1 and the inhibition of these multiple routes of infection involve numerous immunological defenses (55), such as secretory IgA aggregation, Fc-mediated inhibition, neutralization of CD4 T cell infection, lysis of infected cells by NK cells, phagocytosis after antigen presentation, and inhibition following cytokine and chemokine production (Figure 1). For example, HIV-1 trapped by DCs can be inhibited by Fc-mediated inhibitory Abs, whereas inhibition of HIV-1 transfer from DCs to T cells will involve potent HIV NAbs (56). Therefore, in addition to neutralization of HIV-1-infected CD4 T cells by specific bNAbs, numerous additional inhibitory pathways, depending on the amount and type of HIV-1 and on the type of cells in the mucosa, may participate in HIV-1 inhibition and could decrease the concentration of NAbs necessary for protection.

\section{MUCOSAL B-CELL RESPONSES}

A major defensive mechanism from the mucosal immune system involves local production and secretion of IgG and dimeric or multimeric IgA from B-cells (57-60). The initial immune stimulation occurs mainly in mucosa-associated lymphoid tissues, particularly Peyer's patches of the distal ileum and other parts of gut-associated lymphoid tissues $(61,62)$. From these inductive sites the activated B-cells reach peripheral blood by migrating through lymph and draining lymph nodes and subsequently extravagate at secretory effector sites on a competitive basis depending on complementary 


\section{Interaction gp120 / CD4}

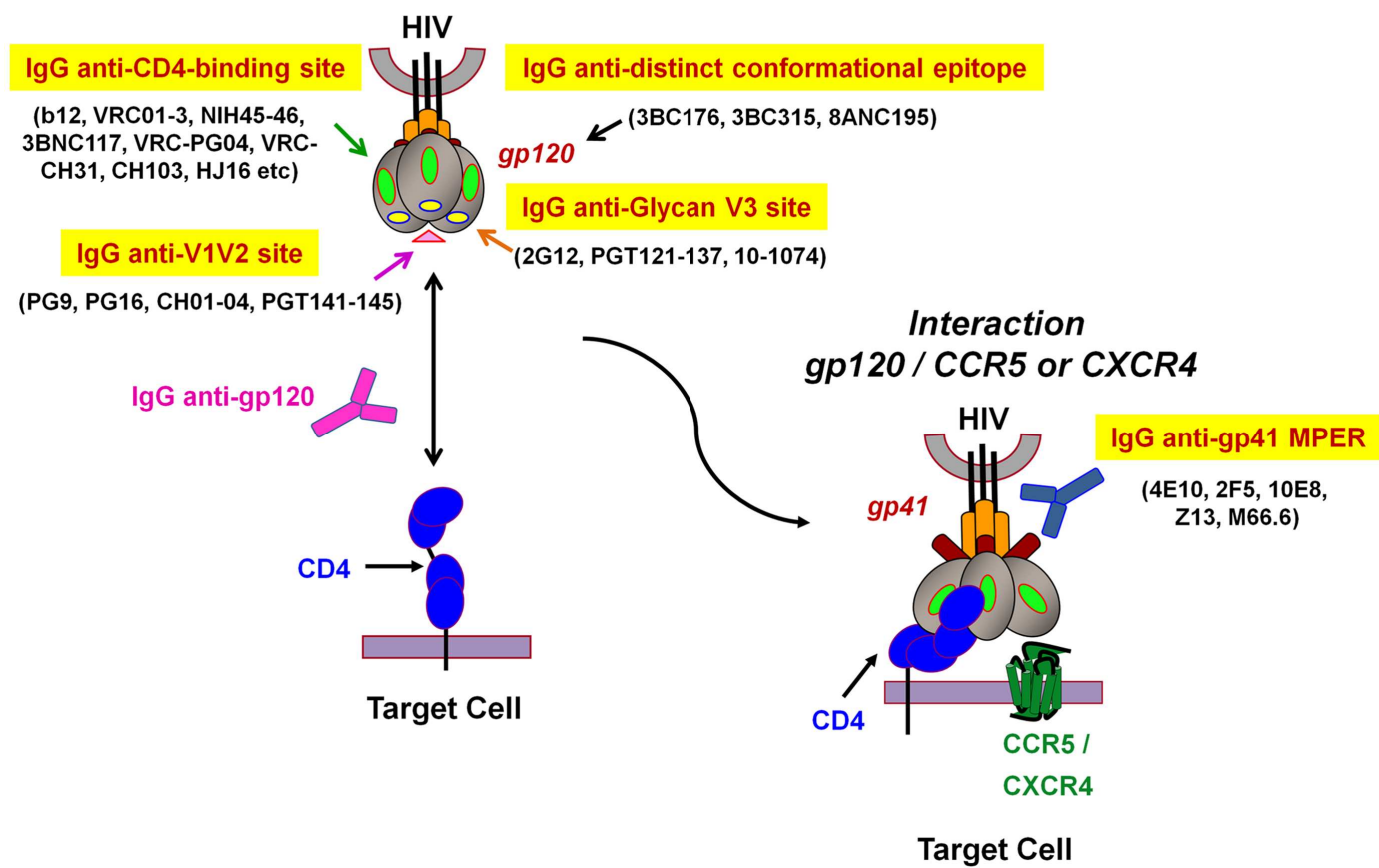

FIGURE 2 | Model representation of HIV-1 envelope glycoprotein structure and epitopes of broadly neutralizing antibodies. The surface receptor binding subunit gp120 and the fusion-mediating transmembrane subunit gp41 make up the functional HIV-1 envelope glycoproteins. The targets of broadly neutralizing antibodies (bNAbs) can be divided into several groups: (1) IgG anti-CD4-binding site, (2) IgG anti-V1V2 site, (3) IgG anti- $N$-linked glycan V3 site, and (4) IgG anti-gp41 membrane proximal external region (MPER). The lgG anti-distinct conformational epitope present on the envelope trimer, remains to be determined (adapted from Dr. Béatrice Labrosse). adhesion molecules and chemokine-receptor pairs $(61,63)$. In addition, B-cells with "innate-like" functions including B-1 cells are enriched in mucosal tissues and marginal zone B-cells (64). These B-cells produce natural Abs that recognize conserved features of bacterial carbohydrates and phospholipids, that generate a first line of protection through the early production of lowaffinity IgM in response to bacteria $(62,64-66)$. Mucosal DCs support B-cell activation and several factors in mucosal tissues, including both $\mathrm{T}$ cell-dependent and $\mathrm{T}$ cell-independent factors have been show to favor B-cell immunoglobulin class-switching to IgA-secreting plasma cells $(59,67)$. However, the exact local production sites and local redistribution at the mucosal site have not been well documented. During acute HIV infection phase, naïve B-cells are immediately decreased and reciprocal memory Bcell increased at mucosal sites and blood although little is known on the phenotypic features and functions of B-cell populations and early B-cell subversions occurring at mucosal sites (68). As most HIV-1 transmission occurs via mucosal sites, eliciting effective mucosal B-cell responses with long-lasting protective NAbs at mucosal sites is therefore critical to provide the first line of protection at mucosal surfaces for preventing early HIV-1 invasion by HIV-1 vaccine (69-71).

\section{MECHANISMS OF INHIBITORY ACTIVITY OF NEUTRALIZING ANTIBODIES}

Most HIV-1 vaccination strategies aim to induce human HIVspecific Abs able to inhibit the infection of target cells at the onset of viral transmission $(2,11,72)$. Humoral responses against HIV have been extensively studied and NAbs able to efficiently neutralize in vitro a broad range of circulating HIV-1 strains have been described $(10,12,20)$. These include the well-characterized NAb b12, 2G12, 447-52D, 2F5, 4E10, as well as novel bNAbs such as VRC01 and 10-1074 or belonging to PGT family that neutralize a large spectrum of HIV-1 isolates of various clades (4-7, 12, 7375) (Figure 2). These Abs efficiently inhibit cell-free HIV primary isolates or pseudoviruses in vitro in conventional neutralization assays with peripheral blood mononuclear cells (PBMCs) or HIVpermissive cell lines (TZM-bl). Both assays assess the capacity of Abs to inhibit HIV-1 infection of either $\mathrm{CD}^{+}{ }^{+}$primary cells or TZM-bl cell lines that express the CD4 receptor and co-receptor CCR5. Abs possessing a neutralizing activity will recognize functionally important structures and conserved epitopes of the HIV viral envelope gp120 and gp41, and will impede virus attachment as well as fusion and entry processes that lead to a decrease in HIV replication (9-12) (Figure 2). The neutralization process is due to the capacity of Abs to directly inhibit HIV-1 replication in the absence of additional factors, such as Fc receptors (FcRs) or complement. Yet, due to the complex glycosylation profile of HIV and conformational changes of the viral envelope during fusion (Figure 2), most NAbs require long HCDR3s to allow the recognition of poorly accessible conserved Env epitopes (76). Moreover, NAbs isolated from infected patients result from a long maturation and somatic hypermutation processes (9-12). These unusual $\mathrm{Ab}$ characteristics will unfortunately be extremely difficult 
to generate by vaccination. Several of these HIV-1 bNAbs have been reverted experimentally to their unmutated ancestral state, and were found to bind weakly or undetectably to native HIV-1 Env $(77,78)$, which means that $\mathrm{Ab}$ responses induced by vaccination will have to occur following intricate pathways of B-cell maturation.

Recent studies showed that high levels of IgG Abs specific for the first and second variable regions (V1V2) of gp120 were inversely associated with a reduced risk of HIV-1 infection in the RV144 clinical vaccine trial $(27,79-81)$. Moreover, Yates et al. recently found that vaccine-induced HIV-1-specific IgG3 responses correlated with decreased risk of infection in RV144 clinical trial compared to the VAX003 vaccine regimen (82). Since partial protection observed in the RV144 phase III Thailand trial was mediated by the induction of non-neutralizing antibodies (NNAbs) and a moderate $\mathrm{T}$ cell response $(27,83)$, it seems that other immune mechanisms in addition to classical NAbs responses are required to achieve protection against HIV infection.

\section{MECHANISMS OF Fc RECEPTOR-MEDIATED PROTECTION}

The FcR-dependent mechanism of inhibition has been observed in various HIV-target cells that express these receptors, for instance DCs, Langerhans cells, and macrophages (56, 84-90). HIV inhibition involving interactions with $\mathrm{FcR}$ receptors was confirmed with the cell line TZM-bl that expresses various Fc $\gamma$ Rs $(91,92)$ mainly Fc $\gamma$ RI and Fc $\gamma$ RII $(84,85,91)$. Fc-mediated inhibition increased by 10 - to 1000 -fold the inhibitory activity of NAbs in FcR-bearing macrophages (84), and neutralization titers of NAbs $4 \mathrm{E} 10$ and 2F5 were increased as much as 5000-fold in the case of TZM-bl cells expressing Fc $\gamma$ RI $(91,92)$. Some HIV-1-specific Abs lacking neutralizing activities have also been shown to display Fc-mediated inhibitory activities (93). Such Abs, which inhibit HIV-1 replication only via $\mathrm{Fc} \gamma \mathrm{R}$ receptors are referred to as nonneutralizing inhibitory Abs (NNIAbs) (85). In the case of APCs bearing $\mathrm{Fc} \gamma \mathrm{R}$, the formation of immune complexes between Abs and HIV leads to phagocytosis of the virus and its degradation by specific lysosomes (88, 94-96). Moreover, the fixation of Abs on the FcR of effector cells can also induce antiviral cytokines and chemokines, further impeding viral replication (97, 98). The mechanism of inhibition of NNIAbs implies that, contrary to NAbs, they do not need to recognize functional Env spikes. NNIAbs capture the virus via the Fab domains and bind to FcR-bearing cells via their Fc domains, increasing therefore the number of potential epitopes susceptible to be targeted by immunogens.

Recently, it has been shown that V1V2-specific IgG3 subclass Abs are associated with broad antiviral responses and were correlated with a decreased risk of infection in the RV144 vaccine trial (82). Chung et al. also found that in this trial, NNAbs were induced that presented highly coordinated Fc-mediated effector responses by the selective induction of highly functional IgG3 (99). These studies indicate that functional activity and Ab subclass may contribute to the potential antiviral activity of Abs that extends beyond virus neutralization and illustrate the potential role of Fc $\gamma$ R-mediated innate and adaptive immune functions in additional HIV-1 protective mechanisms.

\section{ANTIBODY-DEPENDENT CELLULAR CYTOTOXICITY}

Antibody-dependent cellular cytotoxicity was reported in HIVinfected patients in 1987, when it was shown that HIV envelope gp120 bound to CD4 T cells was sensitive to lysis by PBMCs from HIV-infected patients (100). This ADCC mechanism also involves FcRs $(93,101)$, mainly FcRIII (CD16). Cross linking of Abs that recognize an infected target cell via its Fab domain and the FcR on the effector cell via its Fc domain leads to lysis of the infected target cell subsequent to effector cell degranulation (101-105). Various immune cells such as NK cells, monocytes, macrophages, or neutrophils can induce ADCC (106). It has been suggested that ADCC participated in the $31 \%$ reduced risk of HIV infection in the RV144 trial (26). Recent studies showed that ADCC also occurred in elite controllers $(107,108)$. Even though a correlation between in vitro ADCC and protection was not demonstrated, there is evidence that ADCC might account, at least partially, for protection against SHIV/SIV challenge in the in vivo macaque model (109). Hence, inducing Abs with ADCC function might enhance protection and should be considered as a goal in future vaccine approaches.

\section{ANTIBODY-DEPENDENT CELL-MEDIATED VIRUS INHIBITION ACTIVITY}

Antibody-dependent cell-mediated virus inhibition (ADCVI) results from an interaction between an infected target cell and an effector cell expressing one or several Fc $\gamma$ Rs via an HIV-specific Ab. ADCVI encompasses multiple effector functions related to lytic (e.g., ADCC) and non-cytolytic (e.g., production of $\beta$ chemokines) mechanisms leading to a decreased HIV-1 infection and replication $(31,93,95,110)$.

\section{ROLE OF IgA-MEDIATED INHIBITION}

In patients infected with HIV-1, a specific IgA response develops in parallel to the IgG response. Noteworthy, anti-gp41 (but not anti-gp120) IgA Abs were frequently elicited in both plasma and mucosal fluids within the first weeks after transmission. However, shortly after induction, these initial mucosal anti-gp41 Env IgA Abs rapidly declined (111). Later on, during the chronic phase, virusspecific IgA are low in both mucosa and systemic compartments (112). Interestingly, HIV-specific IgA are detected in the genital tract or the seminal fluid in seronegative (in the absence of serological HIV-specific IgG) partners of HIV-positive subjects "highly exposed persistently seronegative” (HEPS) (113-115). Mazzoli et al. first showed that IgA was detected in urine and vaginal samples from HIV-exposed seronegative individuals in the absence of IgG detection (113). In addition, virus-specific IgAs were detected in the salivary secretions of children from seropositive mothers. The presence of $\operatorname{IgA}$ in seronegative subjects that are in regular contact with HIV suggests its potential role in protection.

In vitro, IgA recapitulates for some Abs the neutralizing activity of IgG. In the case of the epitope recognized by NAb b12, the neutralizing activity of IgA was equivalent to that of the IgG (116). Furthermore, IgA displayed an additional inhibitory function involving its Fc region distinct to that of IgG. The presence of IgA at mucosal sites may involve a local activation of different immune mechanisms, such as a secretory component of IgA-mediated protection of mucus-bound IgA in vivo $(117,118)$, the aggregation of 
secretory IgA (119), or mechanisms that involve ADCC effectors cells expressing Fc $\alpha \mathrm{R}$ (such as neutrophils). Recent results from the RV144 vaccine trial demonstrated that the levels of vaccineinduced IgA in serum were associated with a lack of protection against HIV acquisition (27) and that IgA competed with IgG for ADCC activity (120). Anti-HIV IgA therefore interferes with a protective IgG function, impeding its protective potential. On contrary, it was recently shown that the anti-HIV IgA1 isotype protected macaques better than the corresponding IgA2 or IgG Ab types (3). These findings suggest that, depending on their localization and/or structure, vaccine-induced or pre-existing IgA may have either a deleterious effect by competing with potential IgG protective Abs or a significant protective effect by limiting HIV transmission at the mucosal site (3). This dual IgA activity illustrates the complexity of $\mathrm{Ab}$ functions, that depend on the cellular and cytokine environment.

\section{MECHANISMS OF INHIBITION OF HIV CELL-TO-CELL TRANSMISSION}

Numerous studies suggest that direct cell-to-cell transmission occurring early at the mucosal site after sexual transmission makes a major contribution to rapid HIV-1 dissemination throughout the body. This mode of transmission has important consequences for designing treatments or vaccine strategies as inhibition of this type of HIV spread is even more complex than cell-free infection. Inhibitory activity of cell-to-cell spread may depend on donor and target cells such as APC-to-T cell or T cell-to-T cell, on viral strains, multiplicity of viral infection, etc. Consequently, results may diverge and may be controversial $(121,122)$.

Efficient HIV transmission occurs mainly via the formation of virological synapses (123-126). APC-to-T cell and T cell-to-T cell transfer experiments have been used to analyze the inhibitory activity of specific anti-HIV Abs in HIV transmission. By dissecting the early steps of HIV-1 spread from DCs to autologous primary CD4 T lymphocytes, it was shown that NAbs were able to efficiently inhibit HIV-1 transmission to CD4 T lymphocytes (56). Similar inhibitory activities by Abs have also been observed by others (127-131), suggesting that HIV-1 transfer from DCs to $\mathrm{T}$ lymphocytes can be affected by Ab inhibition. Furthermore, Fcmediated inhibitory activity of Abs on the infection of APCs may decrease HIV-1 transmission to surrounding T cells. This is particularly relevant for DCs and macrophages as these cells highly express FcRs (56) [reviewed in Ref. (122)]. Abs can bind FcRs and therefore inhibit HIV-1 transmission via FcR-mediated inhibitory activity. Some NNIAbs such as 246-D have been found to reduce significantly the percentage of infected DCs in vitro (56). For these Abs, a strong association was found between $\mathrm{Fc} \gamma \mathrm{R}$-specific binding capacity, inhibition of HIV-1 replication, and DC maturation. This indicates that the binding of these Abs to DCs induces the maturation of these cells, resulting in lower levels of R5 virus replication (56). However, other authors observed a drastic decrease of Ab inhibitory activity in HIV transfer conditions (51, 54, 132-134). Of note, these later studies mainly involved cell lines in in vitro transfer protocols and the characteristics of the cell-to-cell contact appeared to be determinant for HIV inhibition (54). Close interactions between donor/target cells and immunological synapse formation differ according to the type of cells. DC/lymphocyte crosstalk involves ICAM-1 and LFA-1 adhesion molecules and stabilize interactions (135-139) that are absent with TZM-bl cell lines $(140,141)$. As a result, the strength of the established synapse will influence the efficiency of HIV spread, and the subsequently inhibitory potential of $\mathrm{Abs}(54,56)$. APC/lymphocyte crosstalk can also modulate the immune response $(126,139,142-146)$. Close contact between cells in particular tissues need therefore to be taken into consideration when analyzing HIV transfer. However, very little is currently known about the efficacy of HIV spread and the potency of HIV-specific Abs in different tissue environments.

In addition, during chronic infection, HIV replication propagates in lymphoid organs containing numerous $\mathrm{CD} 4^{+} \mathrm{T}$ lymphocytes $(147,148)$ and cell-to-cell transmission between $\mathrm{T}$ cells is likely to be the most common mode of HIV-1 spread $(124,146$, 149-152). HIV inhibitory activity of Abs on T cell-to-T cell transmission has been extensively studied (51, 53, 54, 133, 153-158), and variable inhibitory activities have been recorded depending on the type of $\mathrm{T}$ cells and virus used. These discrepancies emphasize the necessity to further investigate functional $\mathrm{Ab}$ activities in the context of HIV spread in tissues and lymphoid organs.

\section{ENHANCING ANTIBODIES}

Enhancing Abs were first described as complement-mediated enhancement by Robinson et al. (159, 160). Such Abs, unlike neutralizing or inhibitory Abs, facilitate infection by HIV in vitro by increasing HIV titers (e.g., an increase in the number of infected cells) or by augmenting the production of infectious virus particles. Ab-dependent enhancement of HIV-1 binding and infection of certain cell types has been demonstrated in different in vitro protocols (160-163). However, the mechanism leading to this increase has not been clearly identified although it has been proposed that $\mathrm{Fc}-\mathrm{Fc} \gamma$ receptor interactions or conformational changes in Env or complement receptors may play a role (164-166). The HIV1/IgG complex is able to bind to FcRs and it could therefore be transcytosed by APCs (167). It has also been proposed that virus coated with Abs and taken up via the FcR on DCs may lead to enhancement by FcR-mediated transcytosis of the virus-IgG complex (163). Recently, it was shown that the binding of HIV1-specific Abs to neonatal FcR expressed on epithelial cells could enhance transcytosis of HIV-1 at low $\mathrm{pH}$ (168). Since neonatal FcR was detected in areas of the genital tract that are potentially exposed to HIV-1 during sexual intercourse, this new model of Abdependent enhancement points to an additional mechanism by which sexual transmission of HIV-1 may be facilitated (168). However, no facilitating role of Abs has yet been demonstrated in vivo for HIV infection following vaccination or HIV disease progression (169). There was no evidence of an increased HIV infection among vaccine recipients in the VaxGen and RV144 phase III vaccine trials $(26,170)$. It should be noted that a recent study showed a correlation between the presence of a particular allele of $\mathrm{Fc} \gamma \mathrm{R}$ and an increased risk of infection in a sub-group of volunteers with low risk practices (171). These results suggest a possible deleterious effect of specific HIV Abs in a subpopulation of patients with a particular Fc $\gamma \mathrm{R}$ genotype. Therefore, supplemental studies need to be conducted in future prophylactic vaccine trials in order to circumvent any possible deleterious enhancing effects, since vaccination obviously should avoid the induction of such Abs. 


\section{MECHANISMS OF INHIBITION OF HIV SPREAD IN VIVO BY ANTIBODIES}

The protective role of HIV-specific Abs has been extensively studied in various experimental models of infection, including NHP models (17, 19, 31, 172-178), and humanized mice models (1416). The potential role of Fc $\gamma$ R-mediated innate and adaptive immune functions in addition to neutralization has been repeatedly demonstrated in HIV protection $(32,95,101,110,174,179)$. Neutralizing monoclonal IgG1 b12, devoid of Fc-Fc $\gamma$ R functions has decreased protective potential following vaginal challenge in NHPs (110). NNIAbs were able to reduce the viral load in challenged macaques without conferring complete protection $(31,32)$. These observations clearly indicate that, in addition to neutralization, Fc $\gamma$ Rs are important for achieving protection in vivo. Such effective protection observed in vivo suggests that HIV-specific Abs inhibit infection by cell-free virus and cell-to-cell transmission (Figure 1), both mechanisms contributing to HIV-1 replication and dissemination in the body. Interestingly, the Ab threshold necessary for sterilizing protection decreased in the animal model with decreased virus challenge (174). This further suggests that Abs may display increased potential during sexual transmission in the mucosal environment in the presence of low virus input. In this case, the balance in favor of HIV protection may be more easily achieved by vaccination, as suggested by the partial protection in the RV144 trial observed in a low risk population.

\section{NOVEL UNRAVELED MECHANISM OF ANTIBODY INHIBITION}

Recently, another Ab inhibitory activity was reported that provides protection inside cells by triggering an intracellular immune response in addition to extracellular activities (180). This activity was named ADIN for antibody-dependent intracellular neutralization (181). Working with a non-enveloped virus-like adenovirus as model, it was shown that Abs that bind virus before infection were carried into the cell while attached to the virus particle. Upon escape from the endosomal compartment, these Abs remain bound to the virus allowing it to be detected by the cell. Ab-coated virions are detected by a cytosolic intracellular $\mathrm{Ab}$ receptor called TRIM21, which binds to IgG with a higher affinity than any other $\mathrm{Ab}$ receptor so far described in humans (180, $182,183)$. In addition to its Ab-binding domain, TRIM21 possesses a RING domain with E3 ubiquitin ligase activity. Using this ubiquitination activity, TRIM21 flags the virion for destruction by a mechanism involving proteasomal degradation. This process is very rapid and leads to removal of the virus before transcription and translation of the viral genome, in effect clearing the cell of infection (181). Moreover, it has been shown recently that the TRIM21-mediated ability of antisera to block replication was a consistent feature of the humoral immune response in immunized mice. In the presence of immune sera and upon infection, TRIM21 also activates a proinflammatory response, resulting in secretion of tumor necrosis factor alpha (TNF- $\alpha$ ) and interleukin6 (IL-6) (184). These results demonstrate that TRIM21 provides a potent block to the spreading of infection and induces an antiviral state (184). However, such Ab inhibitory activity may not be relevant to HIV since HIV is an enveloped virus that is uncoated following its entry in host cells. However, if Abs against the core proteins are endocytosed during infection, they may impair later intracellular HIV replication steps. Such an intracellular mechanism may explain some unexpected association between high anti-p24 Ab concentration and decreased viral load $(185,186)$.

Even more intriguing, broader $\mathrm{Ab}$ activities have recently been proposed. The group of Nancy Haigwoog showed an increase of the specific B-cell response, following the passive transfer HIV Abs in a NHP model (187). Using the FrCas mouse retroviral model, Michaud et al. observed a protection linked to the induction of long-term B and T response, due to passive transfer of NAbs (188). This mechanism of stimulation of the adaptive response following Abs transfer was also observed following NAb therapy in infected macaques (17). Such prolonged protection by induction of adaptive immune response by Abs was already described in cancer field (189). These studies attribute an "immunogenic" role to the Abs in that they would be able to induce primary and memory responses more efficiently than free viral particles or infected cells. In this way, Abs could participate in the implementation of an adaptive response, paving the way to new fields of applications.

\section{PROMISE OF HIV ANTIBODIES IN AIDS VACCINES}

Currently, one of the innovating vaccination strategies would consist in developing a mucosal vaccine as an effective means of prevention against HIV sexual transmission (72). The newly identified potent bNAbs that suppress active infections and clear infected cells in humanized mice and macaques suggest that these bNAbs would effectively protect from infection (20). However, in the development of a vaccine against HIV, the possibility of inducing such NAbs have been compromised when it was discovered that they possess unusual characteristics (heavy long chain HCDR3, significant numbers of somatic mutations) that require a long maturation and makes them difficult to induce. The maturation of progenitor B-cells is unlikely to be reproduced by a short stimulation with a single immunogen (8). Vaccination strategies based on a succession of immunogens that would be able to mimic, step by step, the process of maturation, and activation of B-cell clones are currently being tested. However, this approach of vaccination has never been implemented previously and in view of the complex mechanisms that are involved, it is unclear whether it will be successful.

In view of the major, constraints linked to the in vivo induction of NAbs, vaccine approaches involving the optimization of inhibitory Abs, induction of additional immune mechanisms, are currently being examined. These are similar to approaches followed in cancer research, and attempt to modify the Fc region of Abs in order to increase their inhibitory activity. Moldt et al. generated by mutagenesis and by modifying the glycosylation of the Fc region, a panel of mutants of the NAb b12, which retained the neutralizing activity of the Fab region but had different affinity the Fc $\gamma$ Rs $(190,191)$. These Fc modifications increased the affinity of Abs for Fc $\gamma$ Rs as well as the associated in vivo inhibitory functions (phagocytosis, ADCC, etc.). However, no improvement of protection was observed in experimentally challenged macaques.

By inducing inhibitory Abs directly at the sites of infection (anal mucosa, genital tracts, etc.), it might be possible to limit viral replication earlier and in many target cells. New immunogens are currently being formulated in order to redirect the humoral response to mucosal sites (192). A phase 1 clinical trial has recently 
started (European collaborative project EuroNeut41) in order to test this new concept (193). However, these protocols are based on information gathered from the mouse model and local mucosal immune activation could not be reproduced in humans. Unfortunately, our current knowledge on how we could bring the immune response to converge toward mucosa is extremely limited and the mechanisms of action of anti-HIV Abs at mucosal sites are also poorly understood.

In addition to their central role in vaccination, Abs are also being investigated as possible therapeutic agents. Recent studies demonstrate that combinations of cocktails of two or more monoclonal Abs significantly reduced viremia in chronically infected macaques, suggesting that such therapies might be effective in humans $(17,19,32)$. By combining diverse Abs properties to potentiate the protective effects of anti-HIV-specific Ab-based strategies, it might be possible to enhance what was achieved with antiviral compounds by inducing complementary inhibitory potentials gathered by Abs inhibitory functions. A combination of conventional multi-hits antiretroviral therapy with NAbs therapy might be successful and could generate revolutionary drug combinations that may lead to an HIV cure.

\section{SUMMARY AND CONCLUSION}

The last decade has witnessed enormous advances in our knowledge of HIV vaccine designs and trials. Although a large number of broadly and potent NAbs have been recently discovered (Figure 2), inducing such bNAbs by vaccination is likely to be very difficult $(5,7,10)$. Data from in vivo studies and recent findings following clinical assays have demonstrated the importance of Fc-mediated Ab-dependant mechanisms in achieving protection against HIV. Therefore, new vaccination strategies including the induction of such type of activities, in addition to NAbs, should be developed. As HIV transmission at mucosal sites involves specific HIV targets, vaccination should induce an immune response that protects all the different potential mucosal target cells (i.e., using Abs that display different inhibitory activities). Moreover, vaccination should induce Abs and B-cell responses directly at mucosal level in order to rapidly interfere with the early events of HIV infection. Almost nothing is known about the local immune induction at mucosal sites, known to be involved in induction of tolerance. Strategies to develop local immune responses should therefore be encouraged as well as specific adjuvants and immunogens active at the mucosal site leading to a strong and long-lasting response. Furthermore, the protective role of HIV-specific Abs against cell-to-cell transmission should be evaluated by analyzing the transfer of transmitted/founder HIV. It is hoped that improved understanding of HIV transmission via cell-free or cell-associated models and of different functionalities of HIVspecific Abs may lead to a new generation of immunogens and immunotherapeutics for the development of protective and safe vaccine approaches.

\section{ACKNOWLEDGMENTS}

We would like to thank all our colleagues from the INSERM Unit 1110, especially Dr. Maryse Peressin for fruitful discussions; Sylvie Schmidt, Géraldine Laumond, and Thomas Decoville for excellent technical assistance. Figure $\mathbf{2}$ was adapted from Dr. Béatrice Labrosse (INSERM Unit 941), thanks for this generous gift and her support. We thank our financial support from EuroNeut41 (FP7-HELTH-2007-A-201038), EuroPrise (LSHP-CT-2006-037611), VRI (Vaccine Research Institute), Sidaction, ANRS, Dormeur Investment Service, Ltd., and Fonds de Dotation Pierre Berge. Bin Su was supported by a fellowship from ANRS. We apologize to the authors and colleagues whose work is not cited because of space limitations.

\section{REFERENCES}

1. UNAIDS. Global Report: UNAIDS Report on the Global AIDS Epidemic 2012. Geneva: WHO (2012).

2. Mascola JR, Montefiori DC. The role of antibodies in HIV vaccines. Annu Rev Immunol (2010) 28:413-44. doi:10.1146/annurev-immunol-030409-101256

3. Watkins JD, Sholukh AM, Mukhtar MM, Siddappa NB, Lakhashe SK, Kim $\mathrm{M}$, et al. Anti-HIV IgA isotypes: differential virion capture and inhibition of transcytosis are linked to prevention of mucosal R5 SHIV transmission. AIDS (2013) 27:F13-20. doi:10.1097/QAD.0b013e328360eac6

4. Walker LM, Phogat SK, Chan-Hui PY, Wagner D, Phung P, Goss JL, et al. Broad and potent neutralizing antibodies from an African donor reveal a new HIV-1 vaccine target. Science (2009) 326:285-9. doi:10.1126/science.1178746

5. Wu X, Yang ZY, Li Y, Hogerkorp CM, Schief WR, Seaman MS, et al. Rational design of envelope identifies broadly neutralizing human monoclonal antibodies to HIV-1. Science (2010) 329:856-61. doi:10.1126/science.1187659

6. Scheid JF, Mouquet H, Ueberheide B, Diskin R, Klein F, Oliveira TY, et al. Sequence and structural convergence of broad and potent HIV antibodies that mimic CD4 binding. Science (2011) 333:1633-7. doi:10.1126/science.1207227

7. Walker LM, Huber M, Doores KJ, Falkowska E, Pejchal R, Julien JP, et al. Broad neutralization coverage of HIV by multiple highly potent antibodies. Nature (2011) 477:466-U117. doi:10.1038/nature10373

8. Haynes BF, Kelsoe G, Harrison SC, Kepler TB. B-cell-lineage immunogen design in vaccine development with HIV-1 as a case study. Nat Biotechnol (2012) 30:423-33. doi:10.1038/nbt.2197

9. Kwong PD, Mascola JR. Human antibodies that neutralize HIV-1: identification, structures, and B cell ontogenies. Immunity (2012) 37:412-25. doi:10.1016/j.immuni.2012.08.012

10. Klein F, Mouquet H, Dosenovic P, Scheid JF, Scharf L, Nussenzweig MC. Antibodies in HIV-1 vaccine development and therapy. Science (2013) 341:1199-204. doi:10.1126/science.1241144

11. Kwong PD, Mascola JR, Nabel GJ. Broadly neutralizing antibodies and the search for an HIV-1 vaccine: the end of the beginning. Nat Rev Immunol (2013) 13:693-701. doi:10.1038/nri3516

12. Mascola JR, Haynes BF. HIV-1 neutralizing antibodies: understanding nature's pathways. Immunol Rev (2013) 254:225-44. doi:10.1111/imr.12075

13. Gruell H, Klein F. Opening fronts in HIV vaccine development: tracking the development of broadly neutralizing antibodies. Nat Med (2014) 20:478-9. doi: $10.1038 / \mathrm{nm} .3567$

14. Klein F, Gaebler C, Mouquet H, Sather DN, Lehmann C, Scheid JF, et al. Broad neutralization by a combination of antibodies recognizing the CD4 binding site and a new conformational epitope on the HIV-1 envelope protein. J Exp Med (2012) 209:1469-79. doi:10.1084/jem.20120423

15. Klein F, Halper-Stromberg A, Horwitz JA, Gruell H, Scheid JF, Bournazos S, et al. HIV therapy by a combination of broadly neutralizing antibodies in humanized mice. Nature (2012) 492:118-22. doi:10.1038/nature11604

16. Veselinovic M, Neff CP, Mulder LR, Akkina R. Topical gel formulation of broadly neutralizing anti-HIV-1 monoclonal antibody VRC01 confers protection against HIV-1 vaginal challenge in a humanized mouse model. Virology (2012) 432:505-10. doi:10.1016/j.virol.2012.06.025

17. Barouch DH, Whitney JB, Moldt B, Klein F, Oliveira TY, Liu J, et al. Therapeutic efficacy of potent neutralizing HIV-1-specific monoclonal antibodies in SHIVinfected rhesus monkeys. Nature (2013) 503:224-8. doi:10.1038/nature12744

18. McCoy LE, Weiss RA. Neutralizing antibodies to HIV-1 induced by immunization. J Exp Med (2013) 210:209-23. doi:10.1084/jem.20121827

19. Shingai M, Nishimura Y, Klein F, Mouquet H, Donau OK, Plishka R, et al. Antibody-mediated immunotherapy of macaques chronically infected with SHIV suppresses viraemia. Nature (2013) 503:277-80. doi:10.1038/ nature 12746 
20. West AP Jr, Scharf L, Scheid JF, Klein F, Bjorkman PJ, Nussenzweig MC. Structural insights on the role of antibodies in HIV-1 vaccine and therapy. Cell (2014) 156:633-48. doi:10.1016/j.cell.2014.01.052

21. Moog C, Fleury HJ, Pellegrin I, Kirn A, Aubertin AM. Autologous and heterologous neutralizing antibody responses following initial seroconversion in human immunodeficiency virus type 1-infected individuals. J Virol (1997) 71:3734-41.

22. Burrer R, Salmon-Ceron D, Richert S, Pancino G, Spiridon G, Haessig S, et al. Immunoglobulin $\mathrm{G}(\mathrm{IgG})$ and $\operatorname{IgA}$, but also nonantibody factors, account for in vitro neutralization of human immunodeficiency virus (HIV) type 1 primary isolates by serum and plasma of HIV-infected patients. J Virol (2001) 75:5421-4. doi:10.1128/JVI.75.11.5421-5424.2001

23. Binley JM, Lybarger EA, Crooks ET, Seaman MS, Gray E, Davis KL, et al. Profiling the specificity of neutralizing antibodies in a large panel of plasmas from patients chronically infected with human immunodeficiency virus type 1 subtypes B and C. J Virol (2008) 82:11651-68. doi:10.1128/JVI.01762-08

24. Sather DN, Armann J, Ching LK, Mavrantoni A, Sellhorn G, Caldwell Z, et al. Factors associated with the development of cross-reactive neutralizing antibodies during human immunodeficiency virus type 1 infection. J Virol (2009) 83:757-69. doi:10.1128/JVI.02036-08

25. Simek MD, Rida W, Priddy FH, Pung P, Carrow E, Laufer DS, et al. Human immunodeficiency virus type 1 elite neutralizers: individuals with broad and potent neutralizing activity identified by using a high-throughput neutralization assay together with an analytical selection algorithm. J Virol (2009) 83:7337-48. doi:10.1128/JVI.00110-09

26. Rerks-Ngarm S, Pitisuttithum P, Nitayaphan S, Kaewkungwal J, Chiu J, Paris $\mathrm{R}$, et al. Vaccination with ALVAC and AIDSVAX to prevent HIV-1 infection in Thailand. N Engl J Med (2009) 361:2209-20. doi:10.1056/NEJMoa0908492

27. Haynes BF, Gilbert PB, McElrath MJ, Zolla-Pazner S, Tomaras GD, Alam SM, et al. Immune-correlates analysis of an HIV-1 vaccine efficacy trial. $N$ Engl J Med (2012) 366:1275-86. doi:10.1056/NEJMoa1113425

28. Shattock RJ, Moore JP. Inhibiting sexual transmission of HIV-1 infection. Nat Rev Microbiol (2003) 1:25-34. doi:10.1038/nrmicro729

29. Hladik F, Sakchalathorn P, Ballweber L, Lentz G, Fialkow M, Eschenbach D, et al. Initial events in establishing vaginal entry and infection by human immunodeficiency virus type-1. Immunity (2007) 26:257-70. doi:10.1016/j.immuni.2007. 01.007

30. Piguet V, Steinman RM. The interaction of HIV with dendritic cells: outcomes and pathways. Trends Immunol (2007) 28:503-10. doi:10.1016/j.it.2007.07.010

31. Burton DR, Hessell AJ, Keele BF, Klasse PJ, Ketas TA, Moldt B, et al. Limited or no protection by weakly or nonneutralizing antibodies against vaginal SHIV challenge of macaques compared with a strongly neutralizing antibody. Proc Natl Acad Sci U S A (2011) 108:11181-6. doi:10.1073/pnas.1103012108

32. Moog C, Dereuddre-Bosquet N, Teillaud JL, Biedma ME, Holl V, Van Ham G, et al. Protective effect of vaginal application of neutralizing and nonneutralizing inhibitory antibodies against vaginal SHIV challenge in macaques. Mucosal Immunol (2014) 7:46-56. doi:10.1038/mi.2013.23

33. Keele BF, Giorgi EE, Salazar-Gonzalez JF, Decker JM, Pham KT, Salazar MG, et al. Identification and characterization of transmitted and early founder virus envelopes in primary HIV-1 infection. Proc Natl Acad Sci U S A (2008) 105:7552-7. doi:10.1073/pnas.0802203105

34. Wilen CB, Parrish NF, Pfaff JM, Decker JM, Henning EA, Haim H, et al. Phenotypic and immunologic comparison of clade B transmitted/founder and chronic HIV-1 envelope glycoproteins. J Virol (2011) 85:8514-27. doi:10.1128/ JVI.00736- 11

35. Ochsenbauer C, Edmonds TG, Ding H, Keele BF, Decker J, Salazar MG, et al. Generation of transmitted/founder HIV-1 infectious molecular clones and characterization of their replication capacity in CD4 T lymphocytes and monocyte-derived macrophages. J Virol (2012) 86:2715-28. doi:10.1128/JVI. 06157- 11

36. Harman AN, Kim M, Nasr N, Sandgren KJ, Cameron PU. Tissue dendritic cells as portals for HIV entry. Rev Med Virol (2013) 23:319-33. doi:10.1002/rmv. 1753

37. Parker ZF, Iyer SS, Wilen CB, Parrish NF, Chikere KC, Lee FH, et al. Transmitted/founder and chronic HIV-1 envelope proteins are distinguished by differential utilization of CCR5. J Virol (2013) 87:2401-11. doi:10.1128/JVI. 02964- 12
38. Parrish NF, Gao F, Li H, Giorgi EE, Barbian HJ, Parrish EH, et al. Phenotypic properties of transmitted founder HIV-1. Proc Natl Acad Sci U S A (2013) 110:6626-33. doi:10.1073/pnas.1304288110

39. Haase AT. Targeting early infection to prevent HIV-1 mucosal transmission. Nature (2010) 464:217-23. doi:10.1038/nature08757

40. Mesman AW, Geijtenbeek TB. Pattern recognition receptors in HIV transmission. Front Immunol (2012) 3:59. doi:10.3389/fimmu.2012.00059

41. Cunningham AL, Harman A, Nasr N. Initial HIV mucosal infection and dendritic cells. EMBO Mol Med (2013) 5:658-60. doi:10.1002/emmm.201202763

42. Xu H, Wang X, Veazey RS. Mucosal immunology of HIV infection. Immunol $\operatorname{Rev}(2013)$ 254:10-33. doi:10.1111/imr.12072

43. Cavarelli M, Scarlatti G. HIV-1 infection: the role of the gastrointestinal tract. Am J Reprod Immunol (2014) 71:537-42. doi:10.1111/aji.12245

44. Wu L, KewalRamani VN. Dendritic-cell interactions with HIV: infection and viral dissemination. Nat Rev Immunol (2006) 6:859-68. doi:10.1038/nri1960

45. Iwasaki A. Mucosal dendritic cells. Annu Rev Immunol (2007) 25:381-418. doi:10.1146/annurev.immunol.25.022106.141634

46. Carias AM, McCoombe S, McRaven M, Anderson M, Galloway N, Vandergrift N, et al. Defining the interaction of HIV-1 with the mucosal barriers of the female reproductive tract. J Virol (2013) 87:11388-400. doi:10.1128/JVI. 01377-13

47. Cavarelli M, Foglieni C, Rescigno M, Scarlatti G. R5 HIV-1 envelope attracts dendritic cells to cross the human intestinal epithelium and sample luminal virions via engagement of the CCR5. EMBO Mol Med (2013) 5:776-94. doi:10.1002/emmm.201202232

48. Tsunetsugu-Yokota Y, Muhsen M. Development of human dendritic cells and their role in HIV infection: antiviral immunity versus HIV transmission. Front Microbiol (2013) 4:178. doi:10.3389/fmicb.2013.00178

49. Dimitrov DS, Willey RL, Sato H, Chang LJ, Blumenthal R, Martin MA. Quantitation of human immunodeficiency virus type 1 infection kinetics. J Virol (1993) 67:2182-90.

50. Carr JM, Hocking H, Li P, Burrell CJ. Rapid and efficient cell-to-cell transmission of human immunodeficiency virus infection from monocyte-derived macrophages to peripheral blood lymphocytes. Virology (1999) 265:319-29. doi:10.1006/viro.1999.0047

51. Chen P, Hubner W, Spinelli MA, Chen BK. Predominant mode of human immunodeficiency virus transfer between $\mathrm{T}$ cells is mediated by sustained Env-dependent neutralization-resistant virological synapses. J Virol (2007) 81:12582-95. doi:10.1128/JVI.00381-07

52. Sourisseau M, Sol-Foulon N, Porrot F, Blanchet F, Schwartz O. Inefficient human immunodeficiency virus replication in mobile lymphocytes. J Virol (2007) 81:1000-12. doi:10.1128/JVI.01629-06

53. Martin N, Welsch S, Jolly C, Briggs JA, Vaux D, Sattentau QJ. Virological synapse-mediated spread of human immunodeficiency virus type 1 between $\mathrm{T}$ cells is sensitive to entry inhibition. J Virol (2010) 84:3516-27. doi:10.1128/JVI.02651-09

54. Zhong P, Agosto LM, Ilinskaya A, Dorjbal B, Truong R, Derse D, et al. Cellto-cell transmission can overcome multiple donor and target cell barriers imposed on cell-free HIV. PLoS One (2013) 8:e53138. doi:10.1371/journal. pone. 0053138

55. Horton RE, Vidarsson G. Antibodies and their receptors: different potential roles in mucosal defense. Front Immunol (2013) 4:200. doi:10.3389/fimmu. 2013.00200

56. Su B, Xu K, Lederle A, Peressin M, Biedma ME, Laumond G, et al. Neutralizing antibodies inhibit HIV-1 transfer from primary dendritic cells to autologous CD4 T lymphocytes. Blood (2012) 120:3708-17. doi:10.1182/blood-2012-03418913

57. Brandtzaeg P, Johansen FE. Mucosal B cells: phenotypic characteristics, transcriptional regulation, and homing properties. Immunol Rev (2005) 206:32-63. doi:10.1111/j.0105-2896.2005.00283.x

58. Cerutti A, Rescigno M. The biology of intestinal immunoglobulin A responses. Immunity (2008) 28:740-50. doi:10.1016/j.immuni.2008.05.001

59. Cerutti A, Chen K, Chorny A. Immunoglobulin responses at the mucosal interface. Annu Rev Immunol (2011) 29:273-93. doi:10.1146/annurev-immunol031210-101317

60. Chang SY, Ko HJ, Kweon MN. Mucosal dendritic cells shape mucosal immunity. Exp Mol Med (2014) 46:e84. doi:10.1038/emm.2014.16 
61. Brandtzaeg P. Function of mucosa-associated lymphoid tissue in antibody formation. Immunol Invest (2010) 39:303-55. doi:10.3109/08820131003680369

62. Brandtzaeg P. Secretory IgA: designed for anti-microbial defense. Front Immunol (2013) 4:222. doi:10.3389/fimmu.2013.00222

63. Agnello D, Denimal D, Lavaux A, Blondeau-Germe L, Lu B, Gerard NP, et al. Intrarectal immunization and $\operatorname{IgA}$ antibody-secreting cell homing to the small intestine. J Immunol (2013) 190:4836-47. doi:10.4049/jimmunol. 1202979

64. Cerutti A, Cols M, Puga I. Marginal zone B cells: virtues of innate-like antibodyproducing lymphocytes. Nat Rev Immunol (2013) 13:118-32. doi:10.1038/ nri3383

65. Baumgarth N. The double life of a B-1 cell: self-reactivity selects for protective effector functions. Nat Rev Immunol (2011) 11:34-46. doi:10.1038/nri2901

66. Magri G, Miyajima M, Bascones S, Mortha A, Puga I, Cassis L, et al. Innate lymphoid cells integrate stromal and immunological signals to enhance antibody production by splenic marginal zone B cells. Nat Immunol (2014) 15:354-64. doi:10.1038/ni.2830

67. Cerutti A. The regulation of IgA class switching. Nat Rev Immunol (2008) 8:421-34. doi:10.1038/nri2322

68. Levesque MC, Moody MA, Hwang KK, Marshall DJ, Whitesides JF, Amos JD, et al. Polyclonal B cell differentiation and loss of gastrointestinal tract germinal centers in the earliest stages of HIV-1 infection. PLoS Med (2009) 6:e1000107. doi:10.1371/journal.pmed.1000107

69. Haynes BF, Liao HX, Tomaras GD. Is developing an HIV-1 vaccine possible? Curr Opin HIV AIDS (2010) 5:362-7. doi:10.1097/COH.0b013e32833d2e90

70. Haynes BF, Moody MA, Liao HX, Verkoczy L, Tomaras GD. B cell responses to HIV-1 infection and vaccination: pathways to preventing infection. Trends $\mathrm{Mol}$ Med (2011) 17:108-16. doi:10.1016/j.molmed.2010.10.008

71. Friedman J, Alam SM, Shen X, Xia SM, Stewart S, Anasti K, et al. Isolation of HIV-1-neutralizing mucosal monoclonal antibodies from human colostrum. PLoS One (2012) 7:e37648. doi:10.1371/journal.pone.0037648

72. Schiffner T, Sattentau QJ, Dorrell L. Development of prophylactic vaccines against HIV-1. Retrovirology (2013) 10:72. doi:10.1186/1742-4690-10-72

73. Binley JM, Wrin T, Korber B, Zwick MB, Wang M, Chappey C, et al. Comprehensive cross-clade neutralization analysis of a panel of anti-human immunodeficiency virus type 1 monoclonal antibodies. J Virol (2004) 78:13232-52. doi:10.1128/JVI.78.23.13232-13252.2004

74. Polonis VR, Brown BK, Rosa Borges A, Zolla-Pazner S, Dimitrov DS, Zhang MY, et al. Recent advances in the characterization of HIV-1 neutralization assays for standardized evaluation of the antibody response to infection and vaccination. Virology (2008) 375:315-20. doi:10.1016/j.virol.2008.02.007

75. Scheid JF, Mouquet H, Feldhahn N, Seaman MS, Velinzon K, Pietzsch J, et al. Broad diversity of neutralizing antibodies isolated from memory B cells in HIVinfected individuals. Nature (2009) 458:636-40. doi:10.1038/nature07930

76. Julien JP, Sok D, Khayat R, Lee JH, Doores KJ, Walker LM, et al. Broadly neutralizing antibody PGT121 allosterically modulates CD4 binding via recognition of the HIV-1 gp120 V3 base and multiple surrounding glycans. PLoS Pathog (2013) 9:e1003342. doi:10.1371/journal.ppat.1003342

77. Xiao X, Chen W, Feng Y, Zhu Z, Prabakaran P, Wang Y, et al. Germline-like predecessors of broadly neutralizing antibodies lack measurable binding to HIV-1 envelope glycoproteins: implications for evasion of immune responses and design of vaccine immunogens. Biochem Biophys Res Commun (2009) 390:404-9. doi:10.1016/j.bbrc.2009.09.029

78. Ma BJ, Alam SM, Go EP, Lu X, Desaire H, Tomaras GD, et al. Envelope deglycosylation enhances antigenicity of HIV-1 gp41 epitopes for both broad neutralizing antibodies and their unmutated ancestor antibodies. PLoS Pathog (2011) 7:e1002200. doi:10.1371/journal.ppat.1002200

79. Rolland M, Edlefsen PT, Larsen BB, Tovanabutra S, Sanders-Buell E, Hertz T, et al. Increased HIV-1 vaccine efficacy against viruses with genetic signatures in Env V2. Nature (2012) 490:417-20. doi:10.1038/nature11519

80. Gottardo R, Bailer RT, Korber BT, Gnanakaran S, Phillips J, Shen X, et al. Plasma IgG to linear epitopes in the V2 and V3 regions of HIV-1 gp120 correlate with a reduced risk of infection in the RV144 vaccine efficacy trial. PLoS One (2013) 8:e75665. doi:10.1371/journal.pone.0075665

81. Zolla-Pazner S, Decamp AC, Cardozo T, Karasavvas N, Gottardo R, Williams $\mathrm{C}$, et al. Analysis of V2 antibody responses induced in vaccinees in the ALVAC/AIDSVAX HIV-1 vaccine efficacy trial. PLoS One (2013) 8:e53629. doi:10.1371/journal.pone.0053629
82. Yates NL, Liao HX, Fong Y, Decamp A, Vandergrift NA, Williams WT, et al. Vaccine-induced Env V1-V2 IgG3 correlates with lower HIV-1 infection risk and declines soon after vaccination. Sci Transl Med (2014) 6:228-39. doi:10.1126/scitranslmed.3007730

83. Bonsignori M, Pollara J, Moody MA, Alpert MD, Chen X, Hwang KK, et al. Antibody-dependent cellular cytotoxicity-mediating antibodies from an HIV1 vaccine efficacy trial target multiple epitopes and preferentially use the VH1 gene family. J Virol (2012) 86:11521-32. doi:10.1128/JVI.01023-12

84. Holl V, Hemmerter S, Burrer R, Schmidt S, Bohbot A, Aubertin AM, et al. Involvement of Fc gamma RI (CD64) in the mechanism of HIV-1 inhibition by polyclonal IgG purified from infected patients in cultured monocyte-derived macrophages. J Immunol (2004) 173:6274-83. doi:10.4049/jimmunol.173.10. 6274

85. Holl V, Peressin M, Decoville T, Schmidt S, Zolla-Pazner S, Aubertin AM, et al. Nonneutralizing antibodies are able to inhibit human immunodeficiency virus type 1 replication in macrophages and immature dendritic cells. J Virol (2006) 80:6177-81. doi:10.1128/JVI.02625-05

86. Holl V, Peressin M, Schmidt S, Decoville T, Zolla-Pazner S, Aubertin AM, et al. Efficient inhibition of HIV-1 replication in human immature monocytederived dendritic cells by purified anti-HIV-1 IgG without induction of maturation. Blood (2006) 107:4466-74. doi:10.1182/blood-2005-08-3490

87. Peressin M, Holl V, Schmidt S, Decoville T, Mirisky D, Lederle A, et al. HIV-1 replication in Langerhans and interstitial dendritic cells is inhibited by neutralizing and Fc-mediated inhibitory antibodies. J Virol (2011) 85:1077-85. doi:10.1128/JVI.01619-10

88. Ackerman ME, Alter G. Opportunities to exploit non-neutralizing HIVspecific antibody activity. Curr HIV Res (2013) 11:365-77. doi:10.2174/ $1570162 X 113116660058$

89. Ackerman ME, Dugast AS, McAndrew EG, Tsoukas S, Licht AF, Irvine DJ, et al. Enhanced phagocytic activity of HIV-specific antibodies correlates with natural production of immunoglobulins with skewed affinity for FcgammaR2a and FcgammaR2b. J Virol (2013) 87:5468-76. doi:10.1128/JVI.03403-12

90. Peressin M, Proust A, Schmidt S, Su B, Lambotin M, Biedma ME, et al. Efficient transfer of HIV-1 in trans and in cis from Langerhans dendritic cells and macrophages to autologous T lymphocytes. AIDS (2014) 28:667-77. doi:10.1097/QAD.0000000000000193

91. Perez LG, Costa MR, Todd CA, Haynes BF, Montefiori DC. Utilization of immunoglobulin G Fc receptors by human immunodeficiency virus type 1: a specific role for antibodies against the membrane-proximal external region of gp41. J Virol (2009) 83:7397-410. doi:10.1128/JVI.00656-09

92. Perez LG, Zolla-Pazner S, Montefiori DC. Antibody-dependent, Fc gamma RImediated neutralization of HIV-1 in TZM-bl cells occurs independently of phagocytosis. J Virol (2013) 87:5287-90. doi:10.1128/JVI.00278- 13

93. Holl V, Peressin M, Moog C. Antibody-mediated Fcgamma receptor-based mechanisms of HIV inhibition: recent findings and new vaccination strategies. Viruses (2009) 1:1265-94. doi:10.3390/v1031265

94. Ackerman ME, Moldt B, Wyatt RT, Dugast AS, McAndrew E, Tsoukas S, et al. A robust, high-throughput assay to determine the phagocytic activity of clinical antibody samples. J Immunol Methods (2011) 366:8-19. doi:10.1016/j.jim. 2010.12.016

95. Forthal D, Hope TJ, Alter G. New paradigms for functional HIV-specific nonneutralizing antibodies. Curr Opin HIV AIDS (2013) 8:392-400. doi:10.1097/ COH.0b013e328363d486

96. Lewis GK. Qualitative and quantitative variables that affect the potency of Fc-mediated effector function in vitro and in vivo: considerations for passive immunization using non-neutralizing antibodies. Curr HIV Res (2013) 11:354-64. doi:10.2174/1570162X113116660060

97. DeVico AL, Gallo RC. Control of HIV-1 infection by soluble factors of the immune response. Nat Rev Microbiol (2004) 2:401-13. doi:10.1038/ nrmicro878

98. Moody MA, Liao HX, Alam SM, Scearce RM, Plonk MK, Kozink DM, et al. Anti-phospholipid human monoclonal antibodies inhibit CCR5-tropic HIV-1 and induce beta-chemokines. J Exp Med (2010) 207:763-76. doi:10.1084/jem. 20091281

99. Chung AW, Ghebremichael M, Robinson H, Brown E, Choi I, Lane S, et al. Polyfunctional Fc-effector profiles mediated by IgG subclass selection distinguish RV144 and VAX003 vaccines. Sci Transl Med (2014) 6:228-38. doi:10.1126/scitranslmed.3007736 
100. Lyerly HK, Matthews TJ, Langlois AJ, Bolognesi DP, Weinhold KJ. Human T-cell lymphotropic virus IIIB glycoprotein (gp120) bound to CD4 determinants on normal lymphocytes and expressed by infected cells serves as target for immune attack. Proc Natl Acad Sci US A (1987) 84:4601-5. doi:10.1073/pnas.84.13.4601

101. Forthal DN, Moog C. Fc receptor-mediated antiviral antibodies. Curr Opin HIV AIDS (2009) 4:388-93. doi:10.1097/COH.0b013e32832f0a89

102. Trinchieri G, Valiante N. Receptors for the Fc fragment of IgG on natural killer cells. Nat Immun (1993) 12:218-34.

103. Ahmad A, Menezes J. Antibody-dependent cellular cytotoxicity in HIV infections. FASEB J (1996) 10:258-66.

104. Alter G, Altfeld M. NK cells in HIV-1 infection: evidence for their role in the control of HIV-1 infection. J Intern Med (2009) 265:29-42. doi:10.1111/j.13652796.2008.02045.x

105. Berger CT, Alter G. Natural killer cells in spontaneous control of HIV infection. Curr Opin HIV AIDS (2011) 6:208-13. doi:10.1097/COH.0b013e3283457798

106. Smalls-Mantey A, Connors M, Sattentau QJ. Comparative efficiency of HIV1-infected T cell killing by NK cells, monocytes and neutrophils. PLoS One (2013) 8:e74858. doi:10.1371/journal.pone.0074858

107. Lambotte O, Ferrari G, Moog C, Yates NL, Liao HX, Parks RJ, et al. Heterogeneous neutralizing antibody and antibody-dependent cell cytotoxicity responses in HIV-1 elite controllers. AIDS (2009) 23:897-906. doi:10.1097/ QAD.0b013e328329f97d

108. Lambotte O, Pollara J, Boufassa F, Moog C, Venet A, Haynes BF, et al. High antibody-dependent cellular cytotoxicity responses are correlated with strong CD8 T cell viral suppressive activity but not with B57 status in HIV-1 elite controllers. PLoS One (2013) 8:e74855. doi:10.1371/journal.pone.0074855

109. Gomez-Roman VR, Patterson LJ, Venzon D, Liewehr D, Aldrich K, Florese $\mathrm{R}$, et al. Vaccine-elicited antibodies mediate antibody-dependent cellular cytotoxicity correlated with significantly reduced acute viremia in rhesus macaques challenged with SIVmac251. J Immunol (2005) 174:2185-9. doi:10.4049/jimmunol.174.4.2185

110. Hessell AJ, Hangartner L, Hunter M, Havenith CEG, Beurskens FJ, Bakker JM, et al. Fc receptor but not complement binding is important in antibody protection against HIV. Nature (2007) 449:101-U175. doi:10.1038/nature06106

111. Yates NL, Stacey AR, Nolen TL, Vandergrift NA, Moody MA, Montefiori DC, et al. HIV-1 gp41 envelope IgA is frequently elicited after transmission but has an initial short response half-life. Mucosal Immunol (2013) 6:692-703. doi:10.1038/mi.2012.107

112. Mestecky J, Jackson S, Moldoveanu Z, Nesbit LR, Kulhavy R, Prince SJ, et al. Paucity of antigen-specific IgA responses in sera and external secretions of HIV-type 1-infected individuals. AIDS Res Hum Retroviruses (2004) 20:972-88. doi:10.1089/aid.2004.20.972

113. Mazzoli S, Trabattoni D, Lo Caputo S, Piconi S, Ble C, Meacci F, et al. HIVspecific mucosal and cellular immunity in HIV-seronegative partners of HIVseropositive individuals. Nat Med (1997) 3:1250-7. doi:10.1038/nm1197-1250

114. Broliden K, Hinkula J, Devito C, Kiama P, Kimani J, Trabbatoni D, et al. Functional HIV-1 specific IgA antibodies in HIV-1 exposed, persistently IgG seronegative female sex workers. Immunol Lett (2001) 79:29-36. doi:10.1016/ S0165-2478(01)00263-2

115. Tudor D, Derrien M, Diomede L, Drillet AS, Houimel M, Moog C, et al. HIV1 gp41-specific monoclonal mucosal IgAs derived from highly exposed but IgG-seronegative individuals block HIV-1 epithelial transcytosis and neutralize CD4(+) cell infection: an IgA gene and functional analysis. Mucosal Immunol (2009) 2:412-26. doi:10.1038/mi.2009.89

116. Mantis NJ, Palaia J, Hessell AJ, Mehta S, Zhu Z, Corthesy B, et al. Inhibition of HIV-1 infectivity and epithelial cell transfer by human monoclonal IgG and IgA antibodies carrying the b12 V region. J Immunol (2007) 179:3144-52. doi:10.4049/jimmunol.179.5.3144

117. Phalipon A, Cardona A, Kraehenbuhl JP, Edelman L, Sansonetti PJ, Corthesy B. Secretory component: a new role in secretory IgA-mediated immune exclusion in vivo. Immunity (2002) 17:107-15. doi:10.1016/S1074-7613(02)00341-2

118. Corthesy B. Multi-faceted functions of secretory IgA at mucosal surfaces. Front Immunol (2013) 4:185. doi:10.3389/fimmu.2013.00185

119. Stieh D, Gioia C, McRaven M, Cianci G, Kiser P, Hope T. Development of an imaging based virus aggregation assay for vaccine development. Retrovirology (2012) 9(Suppl 2):319. doi:10.1186/1742-4690-9-S2-P319

120. Tomaras GD, Ferrari G, Shen X, Alam SM, Liao HX, Pollara J, et al. Vaccineinduced plasma IgA specific for the $\mathrm{C} 1$ region of the HIV-1 envelope blocks binding and effector function of IgG. Proc Natl Acad Sci U S A (2013) 110:9019-24. doi:10.1073/pnas.1301456110

121. Moris A. Antiviral treatments over cell-to-cell infection: is it just a matter of dose? AIDS (2013) 27:2481-3. doi:10.1097/01.aids.0000432447.45486.03

122. Schiffner T, Sattentau QJ, Duncan CJ. Cell-to-cell spread of HIV-1 and evasion of neutralizing antibodies. Vaccine (2013) 31:5789-97. doi:10.1016/j.vaccine. 2013.10.020

123. Jolly C, Sattentau QJ. Retroviral spread by induction of virological synapses. Traffic (2004) 5:643-50. doi:10.1111/j.1600-0854.2004.00209.x

124. Sattentau QJ. Cell-to-cell spread of retroviruses. Viruses (2010) 2:1306-21. doi:10.3390/v2061306

125. Vasiliver-Shamis G, Dustin ML, Hioe CE. HIV-1 virological synapse is not simply a copycat of the immunological synapse. Viruses (2010) 2:1239-60. doi:10.3390/v2051239

126. Coleman CM, Gelais CS, Wu L. Cellular and viral mechanisms of HIV-1 transmission mediated by dendritic cells. Adv Exp Med Biol (2013) 762:109-30. doi:10.1007/978-1-4614-4433-6_4

127. Frankel SS, Steinman RM, Michael NL, Kim SR, Bhardwaj N, Pope M, et al. Neutralizing monoclonal antibodies block human immunodeficiency virus type 1 infection of dendritic cells and transmission to T cells. J Virol (1998) 72:9788-94.

128. Ketas TJ, Frank I, Klasse PJ, Sullivan BM, Gardner JP, Spenlehauer C, et al. Human immunodeficiency virus type 1 attachment, coreceptor, and fusion inhibitors are active against both direct and trans infection of primary cells. $J$ Virol (2003) 77:2762-7. doi:10.1128/JVI.77.4.2762-2767.2003

129. Cavrois M, Neidleman J, Kreisberg JF, Greene WC. In vitro derived dendritic cells trans-infect CD4 T cells primarily with surface-bound HIV-1 virions. PLoS Pathog (2007) 3:e4. doi:10.1371/journal.ppat.0030004

130. van Montfort T, Thomas AA, Pollakis G, Paxton WA. Dendritic cells preferentially transfer CXCR4-using human immunodeficiency virus type 1 variants to CD4+ T lymphocytes in trans. J Virol (2008) 82:7886-96. doi:10.1128/JVI. 00245-08

131. Yu HJ, Reuter M, McDonald D. HIV traffics through a specialized, surfaceaccessible intracellular compartment during trans-infection of $\mathrm{T}$ cells by mature dendritic cells. PLoS Pathog (2008) 4(8):e1000134. doi:10.1371/ journal.ppat.1000134

132. Abela IA, Berlinger L, Schanz M, Reynell L, Gunthard HF, Rusert P, et al. Cell-cell transmission enables HIV-1 to evade inhibition by potent CD4bs directed antibodies. PLoS Pathog (2012) 8:1002634. doi:10.1371/journal.ppat. 1002634

133. Durham ND, Yewdall AW, Chen P, Lee R, Zony C, Robinson JE, et al. Neutralization resistance of virological synapse-mediated HIV-1 Infection is regulated by the gp41 cytoplasmic tail. JVirol (2012) 86:7484-95. doi:10.1128/JVI.00230-12

134. Sagar M, Akiyama H, Etemad B, Ramirez N, Freitas I, Gummuluru S. Transmembrane domain membrane proximal external region but not surface unit-directed broadly neutralizing HIV-1 antibodies can restrict dendritic cell-mediated HIV-1 trans-infection. J Infect Dis (2012) 205:1248-57. doi:10.1093/infdis/jis183

135. Sanders RW, De Jong EC, Baldwin CE, Schuitemaker JH, Kapsenberg ML, Berkhout B. Differential transmission of human immunodeficiency virus type 1 by distinct subsets of effector dendritic cells. J Virol (2002) 76:7812-21. doi:10.1128/JVI.76.15.7812-7821.2002

136. McDonald D. Dendritic cells and HIV-1 trans-infection. Viruses (2010) 2:1704-17. doi:10.3390/v2081704

137. Rodriguez-Plata MT, Puigdomenech I, Izquierdo-Useros N, Puertas MC, Carrillo J, Erkizia I, et al. The infectious synapse formed between mature dendritic cells and CD4(+) T cells is independent of the presence of the HIV-1 envelope glycoprotein. Retrovirology (2013) 10:42. doi:10.1186/1742-4690-10-42

138. Duncan CJ, Williams JP, Schiffner T, Gartner K, Ochsenbauer C, Kappes J, et al. High-multiplicity HIV-1 infection and neutralizing antibody evasion mediated by the macrophage-T cell virological synapse. J Virol (2014) 88:2025-34 doi:10.1128/JVI.03245-13

139. Su B, Biedma ME, Lederle A, Peressin M, Lambotin M, Proust A, et al. Dendritic cell-lymphocyte cross talk downregulates host restriction factor SAMHD1 and stimulates HIV-1 replication in dendritic cells. J Virol (2014) 88:5109-21. doi:10.1128/JVI.03057-13

140. Tardif MR, Gilbert C, Thibault S, Fortin JF, Tremblay MJ. LFA-1 antagonists as agents limiting human immunodeficiency virus type 1 infection and 
transmission and potentiating the effect of the fusion inhibitor T-20. Antimicrob Agents Chemother (2009) 53:4656-66. doi:10.1128/AAC.00117-09

141. Kondo N, Melikyan GB. Intercellular adhesion molecule 1 promotes HIV1 attachment but not fusion to target cells. PLoS One (2012) 7:e44827. doi:10.1371/journal.pone.0044827

142. Huppa JB, Davis MM. T-cell-antigen recognition and the immunological synapse. Nat Rev Immunol (2003) 3:973-83. doi:10.1038/nri1245

143. Dustin ML, Tseng SY, Varma R, Campi G. T cell-dendritic cell immunological synapses. Curr Opin Immunol (2006) 18:512-6. doi:10.1016/j.coi.2006.05.017

144. Fooksman DR, Vardhana S, Vasiliver-Shamis G, Liese J, Blair DA, Waite J, et al. Functional anatomy of $\mathrm{T}$ cell activation and synapse formation. Annu Rev Immunol (2010) 28:79-105. doi:10.1146/annurev-immunol-030409-101308

145. Hivroz C, Chemin K, Tourret M, Bohineust A. Crosstalk between T lymphocytes and dendritic cells. Crit Rev Immunol (2012) 32:139-55. doi:10.1615/ CritRevImmunol.v32.i2.30

146. Kulpa DA, Brehm JH, Fromentin R, Cooper A, Cooper C, Ahlers J, et al. The immunological synapse: the gateway to the HIV reservoir. Immunol Rev (2013) 254:305-25. doi:10.1111/imr.12080

147. Haase AT. Population biology of HIV-1 infection: viral and CD4+ T cell demographics and dynamics in lymphatic tissues. Annu Rev Immunol (1999) 17:625-56. doi:10.1146/annurev.immunol.17.1.625

148. Sloan RD, Kuhl BD, Mesplede T, Munch J, Donahue DA, Wainberg MA. Productive entry of HIV-1 during cell-to-cell transmission via dynamin-dependent endocytosis. J Virol (2013) 87:8110-23. doi:10.1128/JVI.00815-13

149. Jolly C, Kashefi K, Hollinshead M, Sattentau QJ. HIV-1 cell to cell transfer across an Env-induced, actin-dependent synapse. J Exp Med (2004) 199:283-93. doi:10.1084/jem.20030648

150. Haller C, Fackler OT. HIV-1 at the immunological and T-lymphocytic virological synapse. Biol Chem (2008) 389:1253-60. doi:10.1515/BC.2008.143

151. Jolly C, Welsch S, Michor S, Sattentau QJ. The regulated secretory pathway in CD4 $\mathrm{T}$ cells contributes to human immunodeficiency virus type-1 cellto-cell spread at the virological synapse. PLoS Pathog (2011) 7:e1002226. doi:10.1371/journal.ppat.1002226

152. Dale BM, Alvarez RA, Chen BK. Mechanisms of enhanced HIV spread through T-cell virological synapses. Immunol Rev (2013) 251:113-24. doi:10.1111/imr. 12022

153. Hubner W, McNerney GP, Chen P, Dale BM, Gordon RE, Chuang FY, et al Quantitative 3D video microscopy of HIV transfer across T cell virological synapses. Science (2009) 323:1743-7. doi:10.1126/science.1167525

154. Massanella M, Puigdomenech I, Cabrera C, Fernandez-Figueras MT, Aucher A, Gaibelet G, et al. Antigp41 antibodies fail to block early events of virological synapses but inhibit HIV spread between T cells. AIDS (2009) 23:183-8. doi:10.1097/QAD.0b013e32831efla3

155. Puigdomenech I, Massanella M, Cabrera C, Clotet B, Blanco J. On the steps of cell-to-cell HIV transmission between CD4 T cells. Retrovirology (2009) 6:89. doi:10.1186/1742-4690-6-89

156. Dale BM, McNerney GP, Thompson DL, Hubner W, De Los Reyes K, Chuang FY, et al. Cell-to-cell transfer of HIV-1 via virological synapses leads to endosomal virion maturation that activates viral membrane fusion. Cell Host Microbe (2011) 10:551-62. doi:10.1016/j.chom.2011.10.015

157. Sanchez-Palomino S, Massanella M, Carrillo J, Garcia A, Garcia F, Gonzalez N, et al. A cell-to-cell HIV transfer assay identifies humoral responses with broad neutralization activity. Vaccine (2011) 29:5250-9. doi:10.1016/j.vaccine.2011. 05.016

158. Malbec M, Porrot F, Rua R, Horwitz J, Klein F, Halper-Stromberg A, et al. Broadly neutralizing antibodies that inhibit HIV-1 cell to cell transmission. $J$ Exp Med (2013) 210:2813-21. doi:10.1084/jem.20131244

159. Robinson WE Jr, Montefiori DC, Mitchell WM. A human immunodeficiency virus type 1 (HIV-1) infection-enhancing factor in seropositive sera. Biochem Biophys Res Commun (1987) 149:693-9. doi:10.1016/0006-291X(87)90423-2

160. Robinson WE, Montefiori DC, Mitchell WM. Antibody-dependent enhancement of human immunodeficiency virus type-1 infection. Lancet (1988) 1:790-4. doi:10.1016/S0140-6736(88)91657-1

161. Wigzell H. Immunopathogenesis of HIV infection. J Acquir Immune Defic Syndr (1988) 1:559-65

162. Homsy J, Meyer M, Tateno M, Clarkson S, Levy JA. The Fc and not CD4 receptor mediates antibody enhancement of HIV infection in human cells. Science (1989) 244:1357-60. doi:10.1126/science.2786647
163. van Montfort T, Nabatov AA, Geijtenbeek TB, Pollakis G, Paxton WA. Efficient capture of antibody neutralized HIV-1 by cells expressing DC-SIGN and transfer to CD4+ T lymphocytes. J Immunol (2007) 178:3177-85. doi:10.4049/ jimmunol.178.5.3177

164. Laurence J, Saunders A, Early E, Salmon JE. Human immunodeficiency virus infection of monocytes: relationship to Fc-gamma receptors and antibodydependent viral enhancement. Immunology (1990) 70:338-43.

165. Schutten M, Andeweg AC, Bosch ML, Osterhaus AD. Enhancement of infectivity of a non-syncytium inducing HIV-1 by SCD4 and by human antibodies that neutralize syncytium inducing HIV-1. Scand J Immunol (1995) 41:18-22. doi:10.1111/j.1365-3083.1995.tb03528.x

166. Sullivan N, Sun Y, Binley J, Lee J, Barbas CF III, Parren PW, et al. Determinants of human immunodeficiency virus type 1 envelope glycoprotein activation by soluble CD4 and monoclonal antibodies. J Virol (1998) 72: 6332-8.

167. Baan E, De Ronde A, Stax M, Sanders RW, Luchters S, Vyankandondera J, et al. HIV-1 autologous antibody neutralization associates with mother to child transmission. PLoS One (2013) 8:e69274. doi:10.1371/journal.pone.0069274

168. Gupta S, Gach JS, Becerra JC, Phan TB, Pudney J, Moldoveanu Z, et al. The neonatal $F c$ receptor $(\mathrm{FcRn})$ enhances human immunodeficiency virus type 1 (HIV-1) transcytosis across epithelial cells. PLoS Pathog (2013) 9:e1003776. doi:10.1371/journal.ppat.1003776

169. Montefiori DC, Karnasuta C, Huang Y, Ahmed H, Gilbert P, De Souza MS, et al. Magnitude and breadth of the neutralizing antibody response in the RV144 and Vax003 HIV-1 vaccine efficacy trials. J Infect Dis (2012) 206:431-41. doi:10.1093/infdis/jis367

170. Francis DP, Heyward WL, Popovic V, Orozco-Cronin P, Orelind K, Gee C, et al. Candidate HIV/AIDS vaccines: lessons learned from the World's first phase III efficacy trials. AIDS (2003) 17:147-56. doi:10.1097/00002030-20030124000003

171. Forthal DN, Gabriel EE, Wang A, Landucci G, Phan TB. Association of Fcgamma receptor IIIa genotype with the rate of HIV infection after gp120 vaccination. Blood (2012) 120:2836-42. doi:10.1182/blood-2012-05431361

172. Mascola JR, Stiegler G, Vancott TC, Katinger H, Carpenter CB, Hanson CE, et al. Protection of macaques against vaginal transmission of a pathogenic HIV-1/SIV chimeric virus by passive infusion of neutralizing antibodies. Nat Med (2000) 6:207-10. doi:10.1038/72318

173. Veazey RS, Shattock RJ, Pope M, Kirijan JC, Jones J, Hu Q, et al. Prevention of virus transmission to macaque monkeys by a vaginally applied monoclonal antibody to HIV-1 gp120. Nat Med (2003) 9:343-6. doi:10.1038/nm833

174. Hessell AJ, Poignard P, Hunter M, Hangartner L, Tehrani DM, Bleeker WK, et al. Effective, low-titer antibody protection against low-dose repeated mucosal SHIV challenge in macaques. Nat Med (2009) 15:951-4. doi:10.1038/nm.1974

175. Dereuddre-Bosquet N, Morellato-Castillo L, Brouwers J, Augustijns P, Bouchemal K, Ponchel G, et al. MiniCD4 microbicide prevents HIV infection of human mucosal explants and vaginal transmission of SHIV(162P3) in cynomolgus macaques. PLoS Pathog (2012) 8:e1003071. doi:10.1371/journal. ppat. 1003071

176. Hessell AJ, Epson E, Moldt B, Rakasz E, Pandey S, Sutton WF, et al. Biodistribution of neutralizing monoclonal antibodies IgG1 b12 and LALA in mucosal and lymphatic tissues of rhesus macaques. Retrovirology (2012) 9(Suppl 2):204 doi:10.1186/1742-4690-9-S2-P204

177. Jaworski JP, Kobie J, Brower Z, Malherbe DC, Landucci G, Sutton WF, et al. Neutralizing polyclonal IgG present during acute infection prevents rapid disease onset in SHIVSF162P3-infected infant rhesus macaques. J Virol (2013) 87:10447-59. doi:10.1128/JVI.00049-13

178. Klein K, Veazey RS, Warrier R, Hraber P, Doyle-Meyers LA, Buffa V, et al. Neutralizing $\operatorname{IgG}$ at the portal of infection mediates protection against vaginal simian/human immunodeficiency virus challenge. J Virol (2013) 87:11604-16. doi:10.1128/JVI.01361-13

179. Hidajat R, Xiao P, Zhou Q, Venzon D, Summers LE, Kalyanaraman VS, et al. Correlation of vaccine-elicited systemic and mucosal nonneutralizing antibody activities with reduced acute viremia following intrarectal simian immunodeficiency virus SIVmac251 challenge of rhesus macaques. J Virol (2009) 83:791-801. doi:10.1128/JVI.01672-08

180. Mallery DL, McEwan WA, Bidgood SR, Towers GJ, Johnson CM, James LC. Antibodies mediate intracellular immunity through tripartite 
motif-containing 21 (TRIM21). Proc Natl Acad Sci U S A (2010) 107:19985-90. doi:10.1073/pnas.1014074107

181. McEwan WA, Mallery DL, Rhodes DA, Trowsdale J, James LC. Intracellular antibody-mediated immunity and the role of TRIM21. Bioessays (2011) 33:803-9. doi:10.1002/bies.201100093

182. James LC, Keeble AH, Khan Z, Rhodes DA, Trowsdale J. Structural basis for PRYSPRY-mediated tripartite motif (TRIM) protein function. Proc Natl Acad Sci U S A (2007) 104:6200-5. doi:10.1073/pnas.0609174104

183. Keeble AH, Khan Z, Forster A, James LC. TRIM21 is an IgG receptor that is structurally, thermodynamically, and kinetically conserved. Proc Natl Acad Sci U S A (2008) 105:6045-50. doi:10.1073/pnas.0800159105

184. Watkinson RE, Tam JC, Vaysburd MJ, James LC. Simultaneous neutralization and innate immune detection of a replicating virus by TRIM21. J Virol (2013) 87:7309-13. doi:10.1128/JVI.00647-13

185. Ngo-Giang-Huong N, Candotti D, Goubar A, Autran B, Maynart M, Sicard D, et al. HIV type 1-specific IgG2 antibodies: markers of helper T cell type 1 response and prognostic marker of long-term nonprogression. AIDS Res Hum Retroviruses (2001) 17:1435-46. doi:10.1089/088922201753197105

186. French MA, Tanaskovic S, Law MG, Lim A, Fernandez S, Ward LD, et al. Vaccine-induced IgG2 anti-HIV p24 is associated with control of HIV in patients with a 'high-affinity' FcgammaRIIa genotype. AIDS (2010) 24:1983-90. doi:10.1097/QAD.0b013e32833clce0

187. Ng CT, Jaworski JP, Jayaraman P, Sutton WF, Delio P, Kuller L, et al. Passive neutralizing antibody controls SHIV viremia and enhances B cell responses in infant macaques. Nat Med (2010) 16:1117-9. doi:10.1038/nm.2233

188. Michaud HA, Gomard T, Gros L, Thiolon K, Nasser R, Jacquet C, et al. A crucial role for infected-cell/antibody immune complexes in the enhancement of endogenous antiviral immunity by short passive immunotherapy. PLoS Pathog (2010) 6:e1000948. doi:10.1371/journal.ppat.1000948

189. Abes R, Gelize E, Fridman WH, Teillaud JL. Long-lasting antitumor protection by anti-CD20 antibody through cellular immune response. Blood (2010) 116:926-34. doi:10.1182/blood-2009-10-248609
190. Moldt B, Schultz N, Dunlop DC, Alpert MD, Harvey JD, Evans DT, et al. A panel of IgG1 b12 variants with selectively diminished or enhanced affinity for $\mathrm{Fc}$ gamma receptors to define the role of effector functions in protection against HIV. J Virol (2011) 85:10572-81. doi:10.1128/JVI.05541-11

191. Moldt B, Shibata-Koyama M, Rakasz EG, Schultz N, Kanda Y, Dunlop DC, et al. A nonfucosylated variant of the anti-HIV-1 monoclonal antibody b12 has enhanced Fc gamma RIIIa-mediated antiviral activity in vitro but does not improve protection against mucosal SHIV challenge in macaques. $J$ Virol (2012) 86:6189-96. doi:10.1128/JVI.00491-12

192. Ruffin N, Borggren M, Euler Z, Fiorino F, Grupping K, Hallengard D, et al. Rational design of HIV vaccines and microbicides: report of the EUROPRISE annual conference 2011. J Transl Med (2012) 10:144. doi:10.1186/1479-587610- 144

193. PX'Therapeutics. PX'Therapeutics Annonce l'essai Clinique EuroNeut-41 Portant sur un Vaccin Prophylactique Contre le VIH. Grenoble: BusinessWire (2012) 12 Mars.

Conflict of Interest Statement: The authors declare that the research was conducted in the absence of any commercial or financial relationships that could be construed as a potential conflict of interest.

Received: 11 April 2014; accepted: 03 June 2014; published online: 18 June 2014.

Citation: Su B and Moog C (2014) Which antibody functions are important for an HIV vaccine? Front. Immunol. 5:289. doi: 10.3389/fimmu.2014.00289

This article was submitted to HIV and AIDS, a section of the journal Frontiers in Immunology.

Copyright (c) 2014 Su and Moog. This is an open-access article distributed under the terms of the Creative Commons Attribution License (CC BY). The use, distribution or reproduction in other forums is permitted, provided the original author(s) or licensor are credited and that the original publication in this journal is cited, in accordance with accepted academic practice. No use, distribution or reproduction is permitted which does not comply with these terms. 